\title{
STRENGTHENING HUMAN RESOURCES GOVERNANCE ON PROGRAM SUCCESS DISTRIBUTION AND DEVELOPMENT OF BEEF IN JAMBI PROVINCE, INDONESIA
}

\author{
Maruli Pahantus*, Firmansyah, Hoesni Fachroerrozi, Afriani H. \\ Faculty of Animal Science, University of Jambi, Indonesia \\ *E-mail: pahantusmarulihutabarat@yahoo.com
}

\begin{abstract}
This study aims to analyze the influence of human resource governance and model for strengthening human resources governance in the program the spread and development of cattle that can increase the production and income of farmers in Jambi Province.The research method used is a survey method with a stratified random sampling technique consisting of 3 strata. Data analysis used path analysis andmodel using Analytical Hierarchy Process. Farmers are not fluent in returning livestock to the pattern of cattle noise in several districts in Jambi Province (37.49\%), then quite a lot of them are also able to smoothly return livestock (35.57\%), and only a small percentage fluent (10.27\%). Prospect and Payment partially affectk the welfare of farmers in the local government's cattle rowing pattern program, while Return and Repayment partially affect the success of the regional government's cattle rowing pattern program.
\end{abstract}

\section{KEY WORDS}

Human resources, management, cattle.

For more than two decades Jambi Province still lacks cattle. Evidence of this deficiency is based on data for the period 1995-2020, where the number of cattle entering Jambi Province continues to increase significantly with an average increase of $18.45 \%$ per year. The cause is the increase in beef consumption (an average of $16.89 \%$ growth per year) which cannot be matched by an increase in the cattle population (an average growth of only $1.20 \%$ per year). The Jambi Provincial Government is aware of this condition, therefore Jambi Governor Regulation No. 7 of 2010 was issued concerning the Regional Government Livestock Noise Pattern with the aim of spreading and developing livestock. cattle is done to increase production while increasing income. However, the success of the cattle distribution and development program of the Regional Government of Jambi Province Indonesia has not gone as expected. The success of the cattle distribution and development program in Jambi Province is strongly influenced by the management of human resources, especially technical officers and the breeders themselves.

The results of the research of Firmansyah et al (2014) andMuthalib et al, (2010), lack of supervision from technical officers causes the livestock assistance program to be less successful. Research Wibowo et al (2011) found that there were some deviations made regarding the cattle rolling mechanism. The results of research by Basuno and Suhaeti (2007) on the Community Direct Loan Assistance program, namely that farmers are reluctant to hand over livestock assets to be rolled out. according toElly (2008), farmers who received assistance from cattle mostly failed because the cattle died and some farmers sold their livestock. Therefore, policy on the spread and development of rolling cattle in Jambi Province Indonesia, needs to improve human resource management.

\section{METHODS OF RESEARCH}

The research method used is a survey method which was carried out in 4 districts in Jambi Province Indonesia that received the programdistribution and development of livestockcattle, namely Merangin, Tebo, Batang Hari and Muaro Jambi districts. Measurement of qualitative variables used a questionnaire in the form of a question with a Scala Likert's Summated Rating's which was tested with a test of validity and a test of 
reliability of the instrument. The ordinal scale data was transformed into an interval scale using the Method of Succesive Interval (MSI). The sampling technique used in this research is Stratified Random Sampling (Harun Al Rasyid, 1994). From each stratum/strata, a sampling unit was selected using a simple random sampling technique. The sample size in this research was determined using the iterative method (Harun Al Rasyid, 1994) with the formula:

$$
n=\frac{\left(Z_{1-\alpha}+Z_{1-\beta}\right)^{2}}{\left(U_{p}^{\prime}\right)^{2}}+3
$$

The structural model of path analysis in this study is:

$$
\begin{aligned}
& \mathrm{Y} 1=\rho_{Y 1 Z 1} Z 1+\rho_{Y 1 Z 2} Z 2+\rho_{Y 1 Z 3} Z 3++\rho_{Y 1 Z 4} Z 4+\rho_{Y 1 \varepsilon i} I(1) \\
& \mathrm{Y} 1=\rho_{\mathrm{Y} 1 \mathrm{D} 1} \mathrm{D} 1+\rho_{\mathrm{Y} 1 \mathrm{D} 2} \mathrm{D} 2+\rho_{\mathrm{Y} 1 \mathrm{D} 3} \mathrm{D} 3+\rho_{\mathrm{Y} 1 \varepsilon \mathrm{I}} \mathrm{I}(2) \\
& \mathrm{Y} 2=\rho_{Z 2 P 1} \mathrm{P} 1+\rho_{\mathrm{Z} 2 \mathrm{P} 2} \mathrm{P} 2+\rho_{\mathrm{Z} 2 \mathrm{P} 3} \mathrm{P} 3+\rho_{\mathrm{Z} 2 \mathrm{P} 4} \mathrm{P} 4+\rho_{\mathrm{Z} 2 \mathrm{P} 5} \mathrm{P} 5+\rho_{\mathrm{Z} 2 \varepsilon \mathrm{l}} \mathrm{I}(3) \\
& \mathrm{Y} 2=\rho_{\mathrm{Y} 2 \mathrm{D} 1} \mathrm{D} 1+\rho_{\mathrm{Y} 2 \mathrm{D} 2} \mathrm{D} 2+\rho_{\mathrm{Y} 2 \mathrm{D} 3} \mathrm{D} 3+\rho_{\mathrm{Y} 1 \varepsilon \mathrm{i}} \mathrm{I}(4) \\
& Y 3=\rho_{Y 3 R 1} R 1+\rho_{Y 3 R 2} R 2+\rho_{Y 3 R 3} R 3+\rho_{Y 3 \varepsilon i} I(5) \\
& \mathrm{Y} 3=\rho_{\mathrm{Y} 3 \mathrm{D} 1} \mathrm{D} 1+\rho_{\mathrm{Y} 3 \mathrm{D} 2} \mathrm{D} 2+\rho_{\mathrm{Y} 3 \mathrm{D} 3} \mathrm{D} 3+\rho_{\mathrm{Y} 1 \varepsilon \mathrm{I}} \mathrm{l}(6) \\
& \mathrm{Y} 3=\rho_{\mathrm{Y}_{3} \mathrm{Y}} \mathrm{Y} 1+\rho_{\mathrm{Y}} \mathrm{Y} 2 \mathrm{Y} 2+\rho_{\mathrm{Y} 3 \mathrm{\varepsilon}} \mathrm{I}(7)
\end{aligned}
$$

Information:

$\mathrm{Z1}$ = Farmer compliance in returning or rolling cattle;

$\mathrm{Z} 2$ = Farmer compliance in replacing cattle that died due to negligence;

$\mathrm{Z3}=$ Farmer compliance in following technical instructions and guidance;

$Z 4$ = The compliance of the breeder in taking the risk according to the agreement;

$\mathrm{Y} 1$ = Development of cattle;

$\mathrm{Y} 2$ = Welfare of farmers in the local government's cattle rowdy pattern program;

Y3 = The success of the local government's cattle row pattern program;

$\mathrm{P} 1$ = Personality;

P2 = Purpose;

P3 = Prospect;

P4 = Payment;

P5 = Party;

$\mathrm{R} 1$ = Return;

$\mathrm{R} 2$ = Repayment;

R3 = Risk;

D1 = Child Scroll;

D2 = Parent Scroll;

D3 = Scroll Other Models;

$\rho=$ Path Coefficient;

$\mathrm{E}=$ Residual variable.

To composemodel of strengthening human resource governance in the program distribution and development of cattle that can increase the production and income of farmers in Jambi Provinceat the stages of input, process, output, outcomes and benefits so as to increase the success of various regional government livestock row programs in Jambi Province using Analytical Hierarchy Process.

\section{RESULTS OF STUDY}

Program Success Cattle Spread and Development. The success of the cattle distribution and development program in Jambi Province can be seen from the smoothness of farmers returning their cattle to the noisy pattern of cattle in Jambi Province. The smoothness of breeders returning livestock to the pattern of cattle noise in several districts in 
Jambi Province is quite diverse between cattle rolling patterns, in detail the following table is presented.

Table 1 - Program SuccessCattle Spread and Development

\begin{tabular}{|c|c|c|c|c|c|c|}
\hline \multirow{2}{*}{ No } & \multirow{2}{*}{ Category } & \multicolumn{4}{|c|}{ District } & \multirow{2}{*}{ Average } \\
\hline & & Fight & Tebo & & Muaro Jambi & \\
\hline \multicolumn{7}{|c|}{ Kids Scroll Pattern } \\
\hline 1 & Fluent (\%) & 81.25 & 52.08 & - & 16.13 & 49.82 \\
\hline 2 & Less Lavish (\%) & 18.75 & 45.85 & - & 79.03 & 47.88 \\
\hline 3 & Not smooth (\%) & 0.00 & 2.08 & - & 4.84 & 2.31 \\
\hline \multicolumn{7}{|c|}{ Parent Scroll Pattern } \\
\hline 1 & Fluent (\%) & 0.00 & 63.64 & 41.67 & - & 35,10 \\
\hline 2 & Less Lavish (\%) & 8.70 & 36.36 & 53.33 & - & 32.80 \\
\hline 3 & Not smooth (\%) & 91.30 & 0.00 & 5.00 & - & 32.10 \\
\hline \multicolumn{7}{|c|}{ More Scroll Patterns } \\
\hline 1 & Fluent (\%) & 0.00 & 45.45 & 60.00 & 66.67 & 43.03 \\
\hline 2 & Less Lavish (\%) & 80.00 & 54.55 & 40.00 & 33.33 & 51.97 \\
\hline 3 & Not smooth (\%) & 20.00 & 0.00 & 0.00 & 0.00 & 5.00 \\
\hline \multicolumn{7}{|c|}{ Total } \\
\hline 1 & Fluent (\%) & 27.08 & 53.72 & 33.89 & 27.60 & 35.57 \\
\hline 2 & Less Lavish (\%) & 35.82 & 45.59 & 31.11 & 37.46 & 37.49 \\
\hline 3 & Not smooth (\%) & 37,10 & 0.69 & 1.67 & 1.61 & 10.27 \\
\hline
\end{tabular}

The most common found was that it was not smooth enough to return cattle to the pattern of cattle noise in several districts in Jambi Province (37.49\%), namely not on time for return, the age of the returned cattle was not appropriate, the sex of the returned cattle was exchanged. However, this study also found that quite a number of cattle were also able to smoothly return their cattle to the rowdy pattern of cattle in several districts of Jambi Province, namely $35.57 \%$. In addition, it was found that only a small percentage $(10.27 \%)$ were not able to return their cattle to the cattle row pattern in several districts in Jambi Province. According to Djaelani et al (2009), in an effort to develop cow noise, breeders are provided with practical knowledge through counseling and guidance from the technical office.

The smooth rolling of livestock will determine the success or failure of the assistance program provided by the government. This fact will hinder the achievement of the program's objectives, namely increasing cattle production while increasing the income of farmers. According to Syailendra (2009), the aim of the cattle assistance program carried out by the government is to increase the number of livestock populations through optimizing available resources, improving management, as well as related assistance provided to farmers who form farmer groups.

Research results Akhirrudin and Sadad (2014) there were 23\% of groups whose livestock died, so the automatic funds could no longer be returned, then $15.4 \%$ of groups whose livestock were lost, then $23 \%$ of groups who participated did not pay because most of the group did not return their livestock. In addition, Wibowo et al (2011) found that there were several irregularities made regarding the cattle rolling mechanism. This happened because group members from each village considered the first rowers more difficult to raise livestock because the cows they received were still virgins. Other deviations also occur in the transfer of livestock before the cattle give birth and the rotation of livestock outside the farmer group.

StudySonbait et al (2011) foundcalving intervaland the mortality rate has a positive effect on the return time of cow noise. The higher the mortality rate of livestock, the longer the return time for rowdy cattle, and conversely the lower the mortality rate, the faster the return of livestock. In addition, the longer the experience of raising livestock, the faster the return time of rowdy cattle, and conversely the less experience of raising livestock, the longer the return time of rowdy cattle. The selection of the recipients of the noise must be stricter and the livestock that is distributed must comply with the specifications and enforcement of the rules and the application of sanctions must be stricter in accordance with the agreement letter. According to Djaelani et al (2009), 
The Influence of Farmer's Human Resources. To find out the amount of Personality, Purpose, Prospect, Payment, and Partybreeder againstthe welfare of farmers in the local government's cattle rowing pattern program, and to find out the influence of human resources in the form of Return, Repayment, and Risk on the success of the local government's cattle rowing pattern program, path analysis was used. To test the significance of the path coefficients simultaneously, the hypotheses are formulated as follows: $\mathrm{H}_{0}: \mathrm{P}_{\mathrm{Z1}} \mathrm{P}_{1}=\mathrm{P}_{\mathrm{Z1}} \mathrm{P}_{2}=$ $P_{Z 1} P_{3}=P_{Z 1} P_{4}=P_{Z 1} P_{5}=0$ and $H_{1}$ at least there is a $P_{z 1} P_{i} \neq 0$. The results of the $F$ test analysis obtained the value of Fcount $=23.7256$ with sig. 0.000 which means the null hypothesis is rejected and the alternative hypothesis is accepted, meaning that there is at least one significant (significant) path coefficient value. These results indicate that Personality $\left(P_{1}\right)$, Purpose $\left(P_{2}\right)$, Prospect $\left(P_{3}\right)$, Payment $\left(P_{4}\right)$, and Party $\left(P_{5}\right)$ simultaneously affect thekfarmer welfare in the local government's cattle rowdy pattern program $\left(Y_{2}\right)$.

Based on the t-test, the results for the five paths turned out to be insignificant, namely the path coefficients for Personality $\left(P_{1}\right)$, Purpose $\left(P_{2}\right)$, and Party $\left(P_{5}\right)$, while the other two paths were the Prospect $\left(P_{3}\right)$ and Payment $\left(P_{4}\right)$ path coefficients. is significant. The existence of an insignificant path coefficient indicates that the path coefficient is not significant. For this reason, the path coefficient was calculated again, namely testing the path coefficient simultaneously with the $F$ test. The results of the $F$ test analysis obtained the $F_{\text {count }}=41,6104$ with sig. 0.000 which means the null hypothesis is rejected and the alternative hypothesis is accepted, meaning that there is at least one significant (significant) path coefficient value. These results indicate that the Prospect $\left(\mathrm{P}_{3}\right)$ and Payment $\left(\mathrm{P}_{4}\right)$ paths simultaneously affect thekfarmer welfare in the local government's cattle rowdy pattern program $\left(Y_{2}\right)$. The results of the $t$ test for $Z$ obtained that $P_{Z 1} X_{3}$ and $P_{Z 1} X_{4}$ are significant. This means that Prospect $\left(P_{3}\right)$ and Payment $\left(\mathrm{P}_{4}\right)$ partially affect thekfarmer welfare in the local government's cattle rowdy pattern program $\left(\mathrm{Y}_{2}\right)$.

The results of Hartono's research (2011), the economic conditions of cattle rancher households can be concluded that there is no moderate difference in income from livestock business between breeding patterns and small-scale fattening patterns. Meanwhile, according to research by Amalo et al (2012), increasing beef cattle control by rowdy households has a positive impact on the economic development of rowdy households because beef cattle business is not only considered as savings that can be used at any time by rowdy households to meet cost needs. the big one. Then the research of Setiani et al (2013) concluded that the independent group beef cattle business and the group receiving government assistance had a very significant difference in income

To find out the amount of Return, Repayment, and Risk tokthe success of the local government's cattle row pattern programpath analysis is used. To test the significance of the path coefficients simultaneously, the hypotheses are formulated as follows: $H_{0}: P_{z 1} R_{1}=P_{z 1} R_{2}$ $=P_{Z 1} R_{3}=0$ and $H_{1}$ at least one $P_{Z 1} R_{i} \neq 0$. The results of the $F$ test analysis obtained the value of Fcount $=29.5433$ with sig. 0.000 which means the null hypothesis is rejected and the alternative hypothesis is accepted, meaning that there is at least one significant (significant) path coefficient value. These results indicate that Return $\left(R_{1}\right)$, Repayment $\left(R_{2}\right)$, and Risk $\left(R_{3}\right)$ simultaneously affect the success of the local government's cattle rowing pattern $\operatorname{program}\left(\mathrm{Y}_{3}\right)$.

Based on the t-test, the results for the five paths were found to be insignificant, namely the path coefficient for Risk $\left(R_{3}\right)$, while the other two paths, namely the path coefficients of Return $\left(R_{1}\right)$ and Repayment $\left(R_{2}\right)$ were significant. The existence of an insignificant path coefficient indicates that the path coefficient is not significant. For this reason, the path coefficient was calculated again, namely testing the path coefficient simultaneously with the $\mathrm{F}$ test. The results of the $\mathrm{F}$ test analysis obtained the $\mathrm{F}_{\text {count }}=39.28711$ with sig. 0.000 which means the null hypothesis is rejected and the alternative hypothesis is accepted, meaning that there is at least one significant (significant) path coefficient value. These results indicate that the Return $\left(R_{1}\right)$ and Repayment $\left(R_{2}\right)$ paths simultaneously affect the success of the local government cattle rowing pattern program $\left(Y_{3}\right)$. The results of the $t$ test for $Z$ obtained that $P_{Z 1} R_{1}$ and $P_{Z 1} R_{2}$ are significant. This means that Return $\left(R_{1}\right)$ and Repayment $\left(R_{2}\right)$ partially affect the success of the local government's cattle rowing pattern program $\left(\mathrm{Y}_{3}\right)$. Credit lenders 
or banks still consider agricultural program credit as a high-risk and unprofitable credit (Susanti et al., 2012).

Research Wibowo et al (2011) found that the criteria for prospective breeders who received assistance were not based on predetermined criteria and there were some deviations made regarding the cattle rolling mechanism. Research Wibowo et al (2011) found that the criteria for prospective breeders who received livestock assistance were not based on predetermined criteria, namely that prospective farmers receiving assistance must have experience raising livestock. Prospective breeders who receive assistance must really have a desire to raise livestock because it will greatly affect the success of the program. In addition, Wibowo et al (2011) found that there were several irregularities made regarding the cattle rolling mechanism. This happened because group members from each village considered the first rowers more difficult to raise livestock because the cows they received were still virgins. Other deviations also occur in the transfer of livestock before the cattle give birth and the rotation of livestock outside the farmer group.The results of the research by Ibrahim et al. (2013) showed that the identification and selection of prospective breeders (Prospective Breeders and Prospective Locations) had a significant effect on the productivity of the main cattle and revolving calves in the cattle breeding business development program with a revolving system pattern.

Model for Strengthening Human Resources Governance. To develop a system modeling Model for Strengthening Human Resources Governance in the Program Spread and Development of Cattle That Can Increase Population and Livestock Income in Jambi Provinceusing the Analytical Hierarchy Process, also known as the Analytical Hierarchy Process, is a simple and flexible decision-making method that accommodates creativity in the design of a problem. This method can explain a complex and unstructured situation by: 1) Divide into its parts, 2) Rearrange the parts (or variables) into a hierarchical form, then, 3) Assign a numeric value to each of these variables through the justification of determining the level of importance, and finally 4) Perform a synthesis to determine which variable has the highest priority that must be worked on to obtain the expected output.

$$
\text { Inconsistency }=0.00 \text { with } 0 \text { missing judgments }
$$

Objective: Model for Strengthening Human Resource Governance in the Cattle Distribution and Development Program that Can Increase Population and Livestock Income in Jambi Province

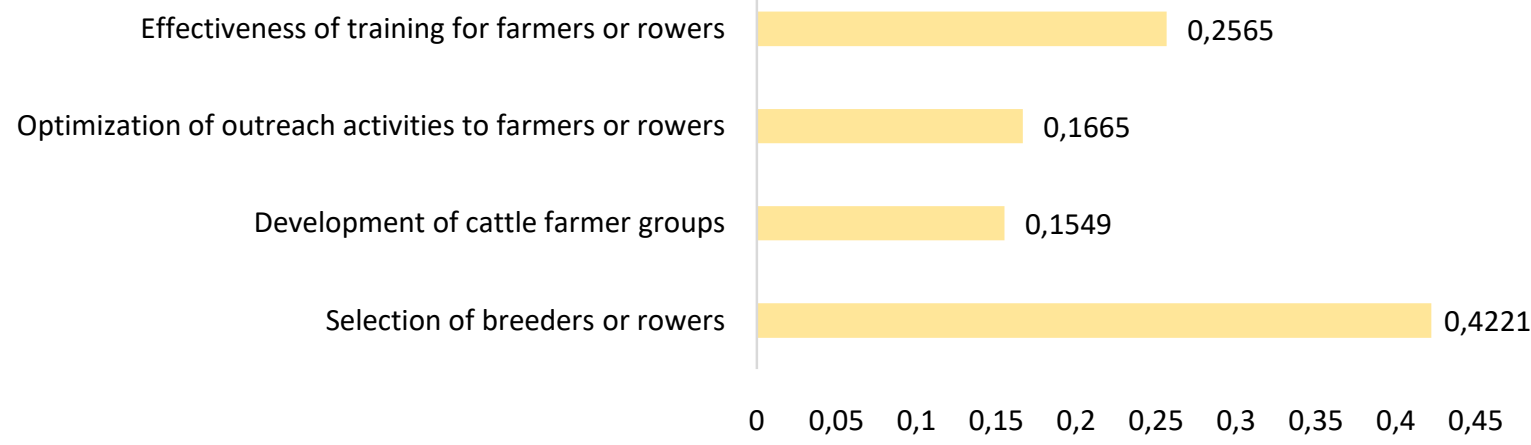

The results of determining the weight of the goal Model of Strengthening Human Resources Governance in the ProgramSpread and Development of Cattle That Can Increase Population and Livestock Income in Jambi Province using the Analytical Hiarchy Process are as follows: 1) Strengthening human resource governance at the input stage (L: 0.328); 2)Strengthening human resource governance at the output stage (L: 0.328); 3)Strengthening human resource governance at the process stage (L: 0.328); 4)Strengthening human resource governance at the outcomes stage (L: 0.328); 5)Strengthening human resource governance at the benefit stage ( $L$ : 0.328). Model of strengthening human resource governance in the programdistribution and development of cattle that can increase the population and income of farmers in Jambi Province has the main goal of strengthening 
human resource management on inputs (L: 0.3567$)$, then followed by strengthening human resource management on the process $(\mathrm{L}: 0.2325$.

The results of determining the weight of the criteria for the Strengthening Model of Human Resources Governance in the Program Spread and Development of Cattle That Can Increase Population and Livestock Income in Jambi Provinceusing the Analytical Hiearchy Process are as follows: 1) Selection of breeders or rowers (L: 0.4221); 2) Development of cattle farmer groups (L: 0.1549); 3) Optimization of outreach activities to farmers or rowers (L: 0.1665); and 4) Effectiveness of training for farmers or rowers (L: 0.2565).

$$
\text { Inconsistency }=0.00 \text { with } 0 \text { missing judgments }
$$

Criteria : Model for Strengthening Human Resource Governance in the Cattle Distribution and Development Program that Can Increase Population and Livestock Income in Jambi Province

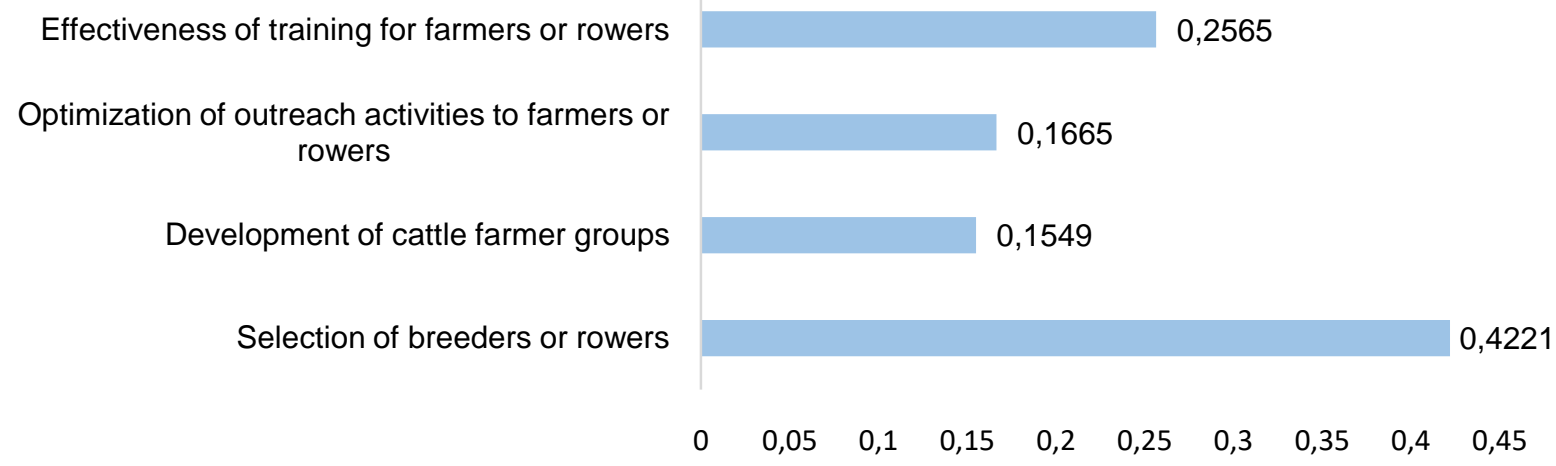

For Strengthening Human Resource Governance on Inputs in the Model for Strengthening Human Resources Governance in ProgramsSpread and Development of Cattle That Can Increase Population and Livestock Income in Jambi ProvinceThe main criteria are the selection of breeders or rowers (L: 0.4221) and the effectiveness of training for farmers or rowers (L: 0.2565). For the Strengthening of Human Resources Governance at the input, the main criteria are the selection of breeders or noisemakers with Standard Operating Procedures policies for breeder selection. Model of strengthening human resource governance in the program distribution and development of cattle that can increase the population and income of farmers in Jambi Provincehas the main objective is to strengthen the governance of human resources on inputs. For the Strengthening of Human Resources Governance at the input, the main criteria are the selection of breeders or noisemakers with SOP policies for breeder selection. According to lyai et al (2020), Good Agricultural Practices (GAPs) will be determined by the human resources available and capacity.

\section{CONCLUSION}

Farmers are not fluent in returning livestock to the pattern of cattle noise in several districts in Jambi Province (37.49\%), then quite a lot of them are also able to smoothly return livestock (35.57\%), and only a small percentage fluent(10.27\%).

Prospect and Payment partially affect the welfare of farmers in the local government's cattle rowing pattern program, while Return and Repayment partially affect the success of the regional government's cattle rowing pattern program.

Model of strengthening human resource governance in the program distribution and development of cattle that can increase the population and income of farmers in Jambi Provincehas the main objective is to strengthen the governance of human resources on inputs. For the Strengthening of Human Resources Governance at the input, the main criteria are the selection of breeders or noisemakers with Standard Operating Procedurespolicies for breeder selection. 


\section{REFERENCES}

1. Akhirrudin and A. Sadad. 2014. Implementation of Revolving Fund Assistance Policy. Journal of Development Administration, Volume 2, Number 3, July 2014, p. 227-360

2. Amalo, S., Budi Hartono and Hari Dwi Utami. 2012. A Simulation Model for Increasing Parent Cattle Noise Patterns for Labor Outflows: A Case Study in Amanuban Selatan District, East Nusa Tenggara Province. Animal Science Vol. 10 (1), March 2012. p. 30-38

3. Basuno, E and R. N Suhaeti. 2007. Analysis of Community Direct Loan Assistance (BPLM): Case of Cattle Business Development in South Sulawesi Province. JournalAgricultural Policy Analysis. Volume 5 No. 2, June 2007: 150-166.

4. Djaelani, S., R. Widiati and KA Santosa. 2009. Community Empowerment through the Beef Cattle Gaduhan Project in Central Oba and North Oba Subdistricts, Tidore Islands, North Maluku.Animal Husbandry Bulletin Vol. 33 (1): 40-48, February 2009. Page: 40-48

5. Firmansyah, B. Rosadi and Parizal, 2014. A Study on Cattle Development in East Tanjung Jabung Regency. Research Report. Cooperation of the Department of Animal Husbandry of East Tanjung Jabung Regency with the Faculty of Animal Husbandry, Jambi University.

6. Harun Al Rashid. 1994. Sampling and Scaling Techniques. edited by Teguh Krismantoroadji et al., Postgraduate Program at Padjadjaran University, Bandung.

7. Hartono. B. 2011. Household Economic Analysis of Beef Cattle Breeders in Damsol District, Donggala Regency, Central Sulawesi Province.Journal of Tropical Livestock Vol. 12, No.1. 2011. Pages: 60-70.

8. Ibrahim, JT, Sutawi and Jayus, 2013. Performance Analysis of Beef Cattle Business Development Program with Revolving System Pattern (Study in Bomberay District, Fakfak Regency, West Papua Province). AGRISE Volume XIII No. May 2, 2013.

9. Iyai, DA, D. Nurhayati, S. Pakage, and I. Widayati. 2020. Impact of Conventional Cattle Farming Systems on Farmer Awareness, Livestock Output and Household Income. Journal of Animal Production Science and Technology. Vol. 08 No. October 3, 2020, Pages: 144-150

10. Muthalib, RA Firmansyah, E. Musnandar. 2010. The Impact of Government Policies on Competitiveness and Efficiency as well as Competitive and Comparative Advantages of People's Cattle Business in the Production Center Areas of Jambi Province. Jambi University Research Journal Science Series. Volume 12, Number 1, January - June 2010

11. Mazdalifa, AF, Islamy, MI, and Putra, P. 2013. Implementation of Agropolitan Area Development Policy in Lamongan Regency. Journal of Public Administration. Vol 1. No. 3. Page: $18-26$

12. Setiani, HE, S. Nur, and OE Djatmiko. 2013. Comparative Analysis of Farmers' Income for the Beneficiary GroupGovernment and Independent Groups in Beef Cattle Farming Groups in Purbalingga Regency. Scientific Journal of Animal Husbandry 1(2): 639 - 646.

13. Sonbait, LY, Santosa and Panjono trains. 2011. Evaluation of the Gaduhan Beef Cattle Development Program through a Group of Independent Institutions Rooted in Communities in Manokwari Regency, West Papua.Animal Husbandry Bulletin Vol. 35(3):208-217, October 2011. Page: 208-217

14. Susanti, I., A. Daryanto, and Muladno. 2012. Government Policy in Financing Cattle Breeding Business.Journal of Management and Agribusiness, Volume 9 Number: 3, November 2012. Page: 137-145

15. Ulum, S., Haryono, BS, and Rozikin, M. 2012. Analysis of the Role of Multi-Actors in the Implementation of Minapolitan Policies Based on Sustainable Development. Journal of Public Administration Research. Vol. 1. No. 1. Pages: 162-170.

16. Wibowo, M.H.S, B. Guntoroand E. Sulastri. 2011. Assessment of Beef Cattle Farming Agribusiness Development Program Implementation in Sekadau Regency, West Kalimantan.Animal Husbandry Bulletin Vol. 35 (2): 143-153, June 2011

17. Winarso, B. 2015. The Success of Beef Cattle Development Through the Business Capital Development Pattern (KUPS). Journal of Applied Agricultural Research Volume 15, Number 2, May 2015. Page: 138-150. 